\title{
An Introspective view of Sustainable Cohousing with The Malaysian Housing Concept
}

\author{
Norhaslina Jumadi ${ }^{1, a}$, Noorsidi Aizuddin Mat Noor ${ }^{1}$, Ahmad Ariffian Bujang ${ }^{1}$ \\ ${ }^{1}$ Department of Real Estate, Faculty of Geoinformation \& Real Estate,Universiti Teknologi Malaysia,81310, UTM Johor Bahru, Malaysia
}

\begin{abstract}
Sustainable development strategies are becoming demanded in assisting in wealth distribution and improving living conditions for mankind. A sustained community is one of the sustainable development agendas that encourage community involvement and participation in contributing to sustainability. Moreover, with the rapid population growth, especially in urban cities as the proportion of urban dwellers will reach two-thirds of the world population, this will lead to several problems including the social life changing intensely. Sustainable Cohousing is one of the suggested answers for an innovative form of neighbourly accommodation. Generally, Cohousing is formed by a group of people who are committed to living as a community and who actively participate in the design and operation to shape their own neighbourhood. Through this concept, the community can decide how they can implement sustainability principles in terms of social, economical and environmental terms in their neighbourhood. Therefore, it is important to bring back the sense of togetherness amongst the people and improve their social wellbeing through an effective neighbourhood. The objective of this study is to isolate the basic concept of Cohousing and to identify the conceptual framework of Sustainable Cohousing that may apply to improving the sustainable living in Malaysia. The research methodology was through identifying and reviewing the issues in existing literature on cohousing chosen from various dimensions, such as principles and elements, sustainable value, development model and so on, which can be suited with the Malaysian culture. The findings of this research are useful for property development practitioners and policy makers in promoting sustainability through the new concept of modern housing.
\end{abstract}

\section{Introduction}

The main objective of sustainable development is to find coherence between three constituent parts, which are environmental sustainability, economic sustainability and socio-political sustainability. Thus, need to be emphasised instead of just development [1]. However, a key issue in implementing sustainability is on how to meet the growing demand for development with the great growth of cities and the number of population, especially at the dawn of the $21^{\text {st }}$ century. As stated by the United Nations under the World Population Prospects: The 2015 Revision, the total world population had reached 7.3 billion people in mid 2015 and the rapid population growth has been recorded, especially in urban cities, as the proportion of urban dwellers will reach two-thirds of the world population and the land converted to urban areas will triple by $2030[2,3]$. This trending is a global phenomenon where Malaysia is no exception. By the year 2030 , it is projected that more than three quarters of the total population will move to the urban areas [4]. This will lead to several problems included in the provision of adequate housing, sanitary facilities and amenities, health and educational facilities, public transportation as well as other infrastructure and many more. Apart from that, due merely to the changing of urbanisation growth, it tends to

\footnotetext{
a Corresponding author: norhaslina.jumadi@gmail.com
}

make the social life change intensely. According to Gidden, the effects of urbanisation on social structures are particularly concerned about the decline of social bonds and solidarity [5]. People will be more independent, selfish, less empathy and ignore interrelations towards each other. Society will become more individualistic and cities will become places full of strangers [6]. Besides that, many social relations now take place outside neighbourhood communities. Virtual social networks seem to be further eroding the residual bonds of spatial proximity and kinship [7]. Therefore, it is important to bring back the sense of togetherness amongst the people and improve their social well being through an effective neighbourhood.

According to Schoenberg, neighbourhoods are seen as possessing "commonly named boundaries, more than one institution identified with the area, and more than one tie of shared public space or social network"[8]. This place can be acceptable for people to live in safety, it is planned and the increase of the feeling of a community's wellbeing. Neighbourhood also can be seen as a frontline to sustainability. One suggested answer to implement sustainability elements in a neighbourhood is through Cohousing [9-11].

This paper presents, literally, the concept, development model, and how this Cohousing will 
accommodate sustainability towards its elements in the Malaysian perspective. Data for this study were merely from previous research using secondary data sources. The initial review of the Cohousing development model and sustainable elements was investigated to seek the potentiality and suitability to be adopted in the Malaysian environment. This was supplemented with a discussion from different scholars regarding the advantages of Cohousing in terms of social, economic and environmental sustainability. An analysis of the secondary data was completed and presented in the table for the overall adaption model of cohousing. Finally, from this, some conclusions have been drawn to the possible outcome of the adaptation of Cohousing in Malaysia as a new sustainable modern housing concept.

\section{Cohousing, a definition}

The idea of forming Cohousing came from Denmark in the mid 1960s by an architect, with only two communities arising from 1970 to 1973 [12]. The idea was accepted and started to spread to other parts of Northern Europe, North America, Great Britain, Australia, New Zealand and Japan [10-11, 13-14]. Cohousing is known as neighbourhoods or developments which are typically formed by a group of people who are "consciously committed to living as a community" [18]. The communities comprise private units (in which households reside) and communal facilities, and they are planned based on Social contract design principles that reportedly encourage more social interaction, helping to build more cohesive communities [15]. Cohousing is currently presumed as a better option to be considered in establishing a sustainable society since its offers people to access and share the ownership in a communal place, supportive cohouser members, greater social responsibility for sustainability and to enjoy the meaning of being a community. In most European countries Cohousing has been established in housing, care and support options for senior residents in order to demonstrate its capacity to enable people to support each other at an older age and through changing life experiences [16]. However, this concept has started to be implemented to other groups of ages; known as Multigenerational Cohousing, since it give a good benefit to social bonding. Adults will enjoy socialising and can share their interests, skills and values to help each other. They will work together and will find a way to improve their living environment. Meanwhilst, for Cohousing children, they will be mentored by the adults and learn a variety of skills and knowledge. Some of the Cohousing communities have provided childcare so that the kids would be taken care of by other cohousers. Hence, they will also set a number of activities to enable socialising amongst the members. On the other hand, they still have a private unit where the cohousers can enjoy their private living. This will give advantages in setting a sustainable society without ignoring the needs of privacy in neighbourhood living.

Remarkably, Cohousing has many variations as it is very dependent on community decisions, such as in terms of size, tenure, principles, and system. However, the universal fundamental elements of cohousing are based on these 6 criteria as per determined by McCamant \& Durrett. The first one is the participatory process where the community manages to get involved in the development process with help from the experts [9]. This will give an extra advantage for them to design their neighbourhood. Secondly, intentional neighbourhood designs which consist of designing sustainable physical forms, such as paths, green zones, parking, etc. For example, they locate the parking at the edge of the site and people will have to pass each other so that every cohouser will meet and greet each other every day. Next, the characteristic is the extensive common facilities, which are seen to be the centre of the community to meet, share and do multiple activities to enjoy the benefits of being a community. The fourth one is that the Cohousing community must set up their own resident management to make decision for any issue dispute through voting, consensus or by a hybrid approach [17]. The fifth criteria of Cohousing are the absence of a hierarchy where no one person (or persons) has authority over the others, and the existence of leaders is acknowledged amongst the others. Lastly, the sixth criteria of Cohousing is in terms of economic factors where a Cohousing community is not a commune and in that sense every cohouser has to find away to earn his or her own money.

The above elements are only a basic idea of Cohousing and not rigid to be followed as it may vary depending on the suitability of the locality. Thus, the criterion can bring positive impacts to the communities in creating sustainable neighbourhoods. Although the process may take time to implement this concept; however, many case studies from various settlements have shown the possibility to be achieved. Cohousing can be seen as one of the solutions for sustainable neighbourhood adoption towards community living.

\section{Sustainability and Cohousing}

According to Charles, Cohousing has shown its value as a successful approach to sustainable housing development by assisting in creating more cooperative, ecologically-sound and socially-just communities and helping to minimize our impact on the earth [18]. Furthermore, other scholars have the belief that the Cohousing concept is primarily based on social relationships and incorporates an adequate sense of environmental awareness. Thus, it automatically brings about savings that are economical in nature through a social and environmental interrelation [19]. Also, according to Marcus and Dovey, Cohousing is a high quality and sustainable alternative to the traditional housing option [20]. Indeed it does appear to fulfill some sustainability objectives: strong social networks and social cohesion, pro-environmental behaviour and a greater sense of well-being amongst residents [21].

Thus, will said that Cohousing is one of the mediums to implement sustainable development through a community; whilst the elements itself can offer support and a sense of unity to people [18]. Moreover, other scholars had described the concept of Cohousing as being a benefit to the environment rather than just the main 
objective in social interrelations. They pointed out that the social and environmental focus in the Cohousing concept automatically brings about savings that are economical in nature [19]. In the meantime, Parker Williams, had agreed by saying that Cohousing can create more sustainable housing, reflecting and embracing nature that can bring inspiration and more livelihoods [22]. Torres-Antonini, Hassel, \& Scanzoni on the other hand, had concluded that Cohousing is a model that is able to address both social and environmental values in a highly effective fashion [23]. Table 1 below summarises the sustainable elements that can be found in Cohousing development from various scholars:

Table 1. Sustainable Elements Towards Cohousing

\begin{tabular}{|c|c|c|c|}
\hline $\begin{array}{l}\text { Sustainable } \\
\text { elements }\end{array}$ & & Findings & $\begin{array}{l}\text { Research } \\
\text { References }\end{array}$ \\
\hline \multirow{3}{*}{ Social } & $\begin{array}{l}\text { Vitality and } \\
\text { security }\end{array}$ & $\begin{array}{l}\text { Strong sense of safety and security due to every } \\
\text { cohouser taking care of each other and together } \\
\text { assisting to make a better, safer environment }\end{array}$ & {$[24]$} \\
\hline & Access & $\begin{array}{c}\text { Strong social and civic fabric, including } \\
\text { volunteering and informal network accessibility }\end{array}$ & {$[25]$} \\
\hline & $\begin{array}{c}\text { Eliminate } \\
\text { social isolation }\end{array}$ & $\begin{array}{c}\text { Strong social networks and social cohesion } \\
\text { amongst the community can be built through this } \\
\text { concept }\end{array}$ & {$[15,10,21]$} \\
\hline Economical & $\begin{array}{l}\text { Generate a } \\
\text { lower cost-of- } \\
\text { living }\end{array}$ & $\begin{array}{l}\text { Encourage sharing of items like tools, gardens, } \\
\text { transportation, laundry facilities, meals, etc }\end{array}$ & {$[22,26,27]$} \\
\hline \multirow[t]{2}{*}{ Environmental } & $\begin{array}{l}\text { Pro } \\
\text { environmental } \\
\text { idea }\end{array}$ & $\begin{array}{l}\text { Pro-environmental will enable the community to } \\
\text { share resources and result in lower levels of } \\
\text { resource consumption including energy, land, } \\
\text { goods and waste production }\end{array}$ & $\begin{array}{l}{[10,18,19,20,} \\
22,28,29]\end{array}$ \\
\hline & $\begin{array}{l}\text { Community } \\
\text { initiative } \\
\text { towards green } \\
\text { building }\end{array}$ & $\begin{array}{c}\text { Incorporate and utilise green building materials } \\
\text { and techniques, and minimise the impact to the } \\
\text { natural environment }\end{array}$ & {$[18,22]$} \\
\hline \multirow{3}{*}{ Physical } & Design & $\begin{array}{l}\text { The design is carefully planned to fulfill } \\
\text { community criteria by which the future needs and } \\
\text { opportunities are defined }\end{array}$ & {$[19,22]$} \\
\hline & $\begin{array}{l}\text { Land use } \\
\text { efficiency }\end{array}$ & $\begin{array}{l}\text { Use the material and land sources efficiently, less } \\
\text { space consumption, preservation of open space } \\
\text { and other remaining land can be prepared for other } \\
\text { community activities }\end{array}$ & [30-31] \\
\hline & Social centre & $\begin{array}{l}\text { Physically, the social centre is the main place } \\
\text { where all the cohousers will be meeting and do all } \\
\text { their activities together, such as dinners, preparing } \\
\text { common meals, meetings, children's plays, etc }\end{array}$ & {$[18,32]$} \\
\hline
\end{tabular}

\section{Cohousing Development Model}

As Cohousing is the most important option to be used in the fulfillment of a sustainable community, therefore, it is important to look over its development models as discussed by J. Williams [15]. The development of Cohousing may vary; however, the two models that have mostly been adapted by cohouser communities are either through new development (grassroot) or reuse of cohousing buildings (retrofit) [32]. The grassroot approach, used for a new development, where residentled model remains as the dominate one to be practiced by most cohouser settlements other than the partnership or speculative Cohousing model. A resident-led model is mainly funded by the residents with the help of an appointed professional. Under this approach, the residents will have the authority and be directly involved in the recruitment, management, and production processes. Further, they will be responsible for all costs and risks associated with the project and liable for any outgoing costs [10]. They may appoint any professionals to help in consulting in the matter or designing, legal forms and technical expects. At the same time, they also have the authority to select or reject their potential neighbourhood (self-selection), who is known to be committed to stay in the community [12]. There are some drawbacks to ponder with this approach especially in terms of funding and managing the project due to its requiring a huge 
commitment and expertise to complete the project. However, surprisingly, this approach has become the popular choice to be adopted by most cohouser communities, especially in Italy, Great Britain, the US, and many more.

The next approach is through the partnership or speculative model which means the residents will cooperate with the developers in managing their project. This will limit their authority but on the good side, they will spread the finance liability, reduce resident's time in managing the project as well as solve the problems of a lack of resources. The difference between these two models is the developer's involvement; where, under the partnership model, the residents will still lead to a certain process especially in selecting the potential neighbourhood, giving input for the design process, and community visioning. The developer is only responsible to develop and manage all the legal requirements and financing. However, under the speculative model, the developers have the authority to decide on all the production and operational processes. The resident is only liable to form a community exercise [10]. This, however, will lead to establishing cohesive communities after completion since all the operational processes are under the developer's responsibilities.

Meanwhilst, retrofit cohousing is another alternative to be adapted by existing communities who are interested in staying and making their livelihood in the Cohousing. Retrofit Cohousing requires the involvement of making use of existing buildings and creating new Cohousing patterns. Under retrofit, the community can also apply any of the three models as mentioned above but the production process is limited in terms of delivery and the design of the physical structure. Although there is a limitation of the design, the residents can still reduce the level of commitment, risk and resources by essentially working with existing stocks and infrastructure [10]. A summary of the Cohousing development models is show as in Table 2 below:

Table 2. Cohousing Development Model

\begin{tabular}{|c|c|c|c|c|c|}
\hline \multirow{2}{*}{$\begin{array}{l}\text { Development } \\
\text { Model }\end{array}$} & \multirow[t]{2}{*}{ Description } & \multicolumn{2}{|c|}{ Responsibilities } & \multirow[t]{2}{*}{ Note } & \multirow{2}{*}{$\begin{array}{c}\text { Exemplar of } \\
\text { Existing community }\end{array}$} \\
\hline & & Resident & Developer & & \\
\hline $\begin{array}{l}\text { Resident }- \text { led } \\
\text { model }\end{array}$ & $\begin{array}{l}\text { Resident leads } \\
\text { from the } \\
\text { design, process } \\
\text { until } \\
\text { production } \\
\text { together with } \\
\text { forming the } \\
\text { community }\end{array}$ & $\begin{array}{l}\text { - Design (with help } \\
\text { from professional) } \\
\text { - Community } \\
\text { recruitment } \\
\text { - Legal and financing } \\
\text { - Community } \\
\text { development } \\
\text { - Production process }\end{array}$ & None & $\begin{array}{l}\text { - } \text { Requires expertise and } \\
\text { commitment in funding the } \\
\text { overall cost of the project } \\
\text { - Still needs professional help in } \\
\text { the design stage and building } \\
\text { community } \\
\text { - Have mutual authority to } \\
\text { select potential neighbour }\end{array}$ & $\begin{array}{l}\text { The community } \\
\text { Project (Laughton, } \\
\text { East Sussesx, } \\
\text { England), The } \\
\text { Village (Madison, } \\
\text { Wisconsin), Rio } \\
\text { Selva (Preganziol, } \\
\text { veneto, Italy) }\end{array}$ \\
\hline $\begin{array}{l}\text { Partnership } \\
\text { model }\end{array}$ & $\begin{array}{l}\text { Developers and } \\
\text { residents work } \\
\text { together } \\
\text { through all the } \\
\text { development } \\
\text { processes with } \\
\text { the lead from } \\
\text { the residents }\end{array}$ & $\begin{array}{l}\text { - Community } \\
\text { recruitment } \\
\text { - Community } \\
\text { development }\end{array}$ & $\begin{array}{l}\text { - Design (with } \\
\text { input from } \\
\text { residents) } \\
\text { - Legal and } \\
\text { financing } \\
\text { - Production } \\
\text { process }\end{array}$ & $\begin{array}{l}\text { - Burden of finance can be } \\
\text { reduced by spreading it to the } \\
\text { developers } \\
\text { - Residents still have authority } \\
\text { in deciding their potential } \\
\text { neighbours } \\
\text { - Give better benefit due to } \\
\text { developer's construction } \\
\text { experience, familiarity of } \\
\text { supply chains and other } \\
\text { project management } \\
\text { knowledge }\end{array}$ & $\begin{array}{c}\text { Threshold Centre, } \\
\text { Village Hill } \\
\text { Cohousing, } \\
\text { (Northampton, } \\
\text { Massachusetts), } \\
\text { Doyle Street } \\
\text { Cohousing } \\
\text { Emeryville, } \\
\text { California } \\
\end{array}$ \\
\hline $\begin{array}{l}\text { Speculative } \\
\text { model }\end{array}$ & $\begin{array}{c}\text { Top-down } \\
\text { approach } \\
\text { where the } \\
\text { developers are } \\
\text { solely } \\
\text { responsible for } \\
\text { the } \\
\text { development } \\
\text { process }\end{array}$ & $\begin{array}{l}\text { - Community } \\
\text { development } \\
\text { (once living in } \\
\text { community) }\end{array}$ & $\begin{array}{l}\text { - Design (with } \\
\text { help from } \\
\text { professional) } \\
\text { - Community } \\
\text { recruitment } \\
\text { - Legal and } \\
\text { financing } \\
\text { - Production } \\
\text { process }\end{array}$ & $\begin{array}{l}\text { - The community are } \\
\text { empowered to build their } \\
\text { community after the project } \\
\text { completion } \\
\text { - All the design, requirements } \\
\text { and production are based on } \\
\text { the developer's decision } \\
\text { - Less time consuming due to } \\
\text { the expert being responsible } \\
\text { for all processes } \\
\text { - The decision power in } \\
\text { designing the physical } \\
\text { building and other facilities } \\
\text { comes solely from the } \\
\text { developer }\end{array}$ & $\begin{array}{c}\text { Swan's Market } \\
\text { Downtown } \\
\text { Oakland, California }\end{array}$ \\
\hline
\end{tabular}

Source: Adapted from Williams J., 2008; Davis, 2001(unpublished); M.L. Ruiu, 2015; and researcher, 2015 


\section{Fitting Sustainable Cohousing In Malaysia}

As Malaysia is committed to setting a future direction in ensuring the sustainability of the housing sector as provided by National Housing Policy under Thrust 5, a proposal of sustainable Cohousing is urged to be deliberated. According to this policy, the efforts to enhance the sustainability of the housing sector are implemented by both the Government and the private sector which want to balance the development implementation and the use of an environmentallyfriendly housing development concept. Through new technologies and innovations towards sustainability indirectly, there will be an elevation of the quality of life as well as a preservation of the environment. Its also suggested that developers are advised to develop a neighbourhood that promotes sustainability as house buyers generally are willing to pay more to live in a sustainable neighbourhood [33]. Moreover, Tan, pointed out that in order to embrace the concept of building communities, private and public developers should envision the process from the community's point of view since they are the one who will enjoy living there rather than merely building properties [37]. Thus, the agenda is initially related to sustainability and Cohousing elements especially in enhancing social-environmental terms through the communities' participants.

Basically, the Cohousing model is distinct from conventional housing development models where the residents will be the decision makers on how their neighbourhood will be, especially on the design and materials of their future homes, by consensus [14]. Therefore, the collective responsibility of the Cohousing development also needs a commitment from the local planners who are familiar with legal and practical accountability for the development process, builders and architects in the construction process and support from the government in the approval matters. As such, in the UK, their local authorities are committed to giving positive responses towards the development of Cohousing in their local plan, identifying potential sites, using planning exceptions and so on. Meanwhilst, in the US, the Cohousing Association has been established to act as a clearinghouse of information about the Cohousing developments. The city government also helps to encourage Cohousing by creating zoning policies that foster the type of dense development that includes Cohousing. On the other hand, in Australia, the Cohousing development is based on collaboration between government-funded community and jointly with other Cooperative and Public Housing Authorities. This will show their commitment in producing more Cohousing for the locality.

As in Malaysia, the Local Authority, Town Planner, Policy maker and developer will be the important organisation to encourage the development of Cohousing. These parties are directly involved with the community and sector cooperation to ensure sustainability in each development. Adaptation to Cohousing development can be grassroots or retrofit by looking at the suitability in the locality. The best way to adopt this concept is through collaboration between the residents and the developer as the residents are limited in funding and land resources. The government may support this project by assisting in setting new housing and planning policies at local and national levels regarding Cohousing by allowing planning permission on an exception of housing development, which is more sustainable features. The commitment from local authority departments such as the planning and housing division with better joint working amongst the community and greater communication about the Cohousing model and its benefits in local development plans will ensure the successfulness of this concept. Moreover, the Local Agenda 21 Programme (LA21), which emphasises the role of the Local Authority in the implementation of Agenda 21 and the sustainable development to be implemented at the local level, will bring a great opportunity to the Cohousing concept. This agenda was established for the government and local communities in working together towards sustainable development. As Cohousing is referred to as sustainable medium by many scholars, community involvement in building their neighbourhood is a core element in Cohousing, therefore, the objective in LA21 can be achieved.

Moreover, the value of Cohousing seems to be similar with the Malaysian culture; thus, it will make this concept easy to accept and it can be the top option for the people to choose as a place to stay. As such, if we look at the traditional Malay kampong, the elements of the social interrelation amongst the neighbours are already established. Houses that are arranged facing each other encourage public surveillance, indirectly creating a safe living environment and a sense of belonging [34]. Furthermore, the social interaction can be found during the conducting of kenduri, or feasts held for weddings, celebrating events and other special occasions. This is a special medium for the residents to meet and help each other (gotong-royong) in preparing the food, and some of the villagers will bring their own food items to share during the kenduri [35]. In terms of decision making, the ketua kampung (village head) will be the one who will lead the residents; however, his decision is still an attempt with the group opinion which is held under the community meeting. There are also community centres (balai raya) and open spaces where the residents can meet, share leisure time and do their activities together. Sometimes, places of worship like a mosque or temple will be the centre of the community to foster their activities and celebrate an occasion. The other main element is the universal value since Malaysia is a multi racial country and thus, racial groups will respect each other's right to foster their relationships [36]. Since thus elements are alike to Cohousing, then the idea will be not difficult to be adapted by Malaysian. Consequently, it will increase the marketability not only benefitting the society but also the stakeholders as a whole.

The elements of Cohousing depend on the locality; therefore, this research suggested a 7-element idea of sustainable Cohousing to be implemented in Malaysia. This idea is based on the social culture and the suitability of the present Cohousing elements. Details of the 
descriptions of the Cohousing element idea are presented

in Figure 1 and Table 3.

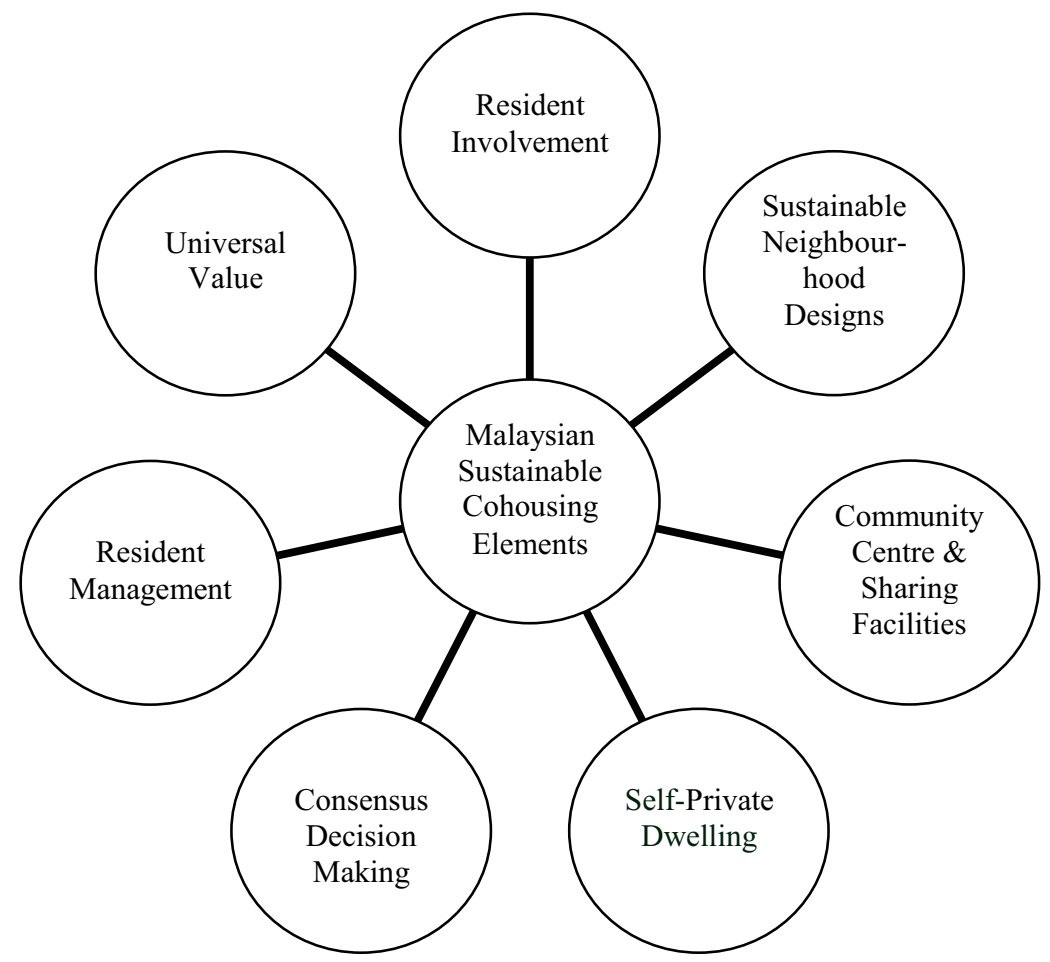

Figure 1. The idea of the 7-Element Sustainable Cohousing in Malaysia

Table 3. Description Idea of the 7 elements of sustainable Cohousing

\begin{tabular}{|c|c|}
\hline $\begin{array}{c}\text { Malaysian Sustainable } \\
\text { Cohousing Elements }\end{array}$ & Description Idea \\
\hline $\begin{array}{c}\text { Resident Involvement In } \\
\text { Development Process }\end{array}$ & $\begin{array}{c}\text { Residents are actively involved in the development process starting from } \\
\text { the initial stage to form a sense of community with help from the experts. }\end{array}$ \\
\hline $\begin{array}{c}\text { Sustainable Neighbourhood } \\
\text { Designs }\end{array}$ & $\begin{array}{c}\text { The layout design needs to show a strong sense of community by } \\
\text { encouraging social contact, a safe environment, and a friendly and } \\
\text { sustainable neighbourhood. }\end{array}$ \\
\hline $\begin{array}{c}\text { Community Centre And Sharing } \\
\text { Facilities }\end{array}$ & $\begin{array}{c}\text { A community centre will be created as a communal place to do their } \\
\text { activities and share their resources with adequate public facilities and } \\
\text { utilities. }\end{array}$ \\
\hline $\begin{array}{c}\text { Self-Private Dwelling } \\
\text { unit. }\end{array}$ \\
\hline Consensus Decision Making & Residents still have a right to stay in theirions owndividual \\
\hline Resident Management & Self-managing communities are independently governed by the residents. \\
\hline Universal Value & $\begin{array}{c}\text { Good interaction in the multi racial and cultural community with respect } \\
\text { to fostering relationships. }\end{array}$ \\
\hline
\end{tabular}

\section{Findings and Conclusion}

In short, this paper has illustrated an alternative housing development concept, other than conventional housing, which is more sustainable to the modern lifestyle in Malaysia. Sustainable development can only be achieved if it can meet three primary objectives which are economically viable, socially acceptable, and technically feasible [3714].
As the population in urban areas keeps growing, the problems of the urban social structure will also be affected by the increasing social isolation, declining social bonding, individualistic community and many more. Therefore, Cohousing is perhaps the most sustainable model to be applied since the characteristics themselves fulfill a sustainable value through the community. Below are suggestions for the conceptual framework of sustainable cohousing to be implemented in Malaysia (Figure 2). 


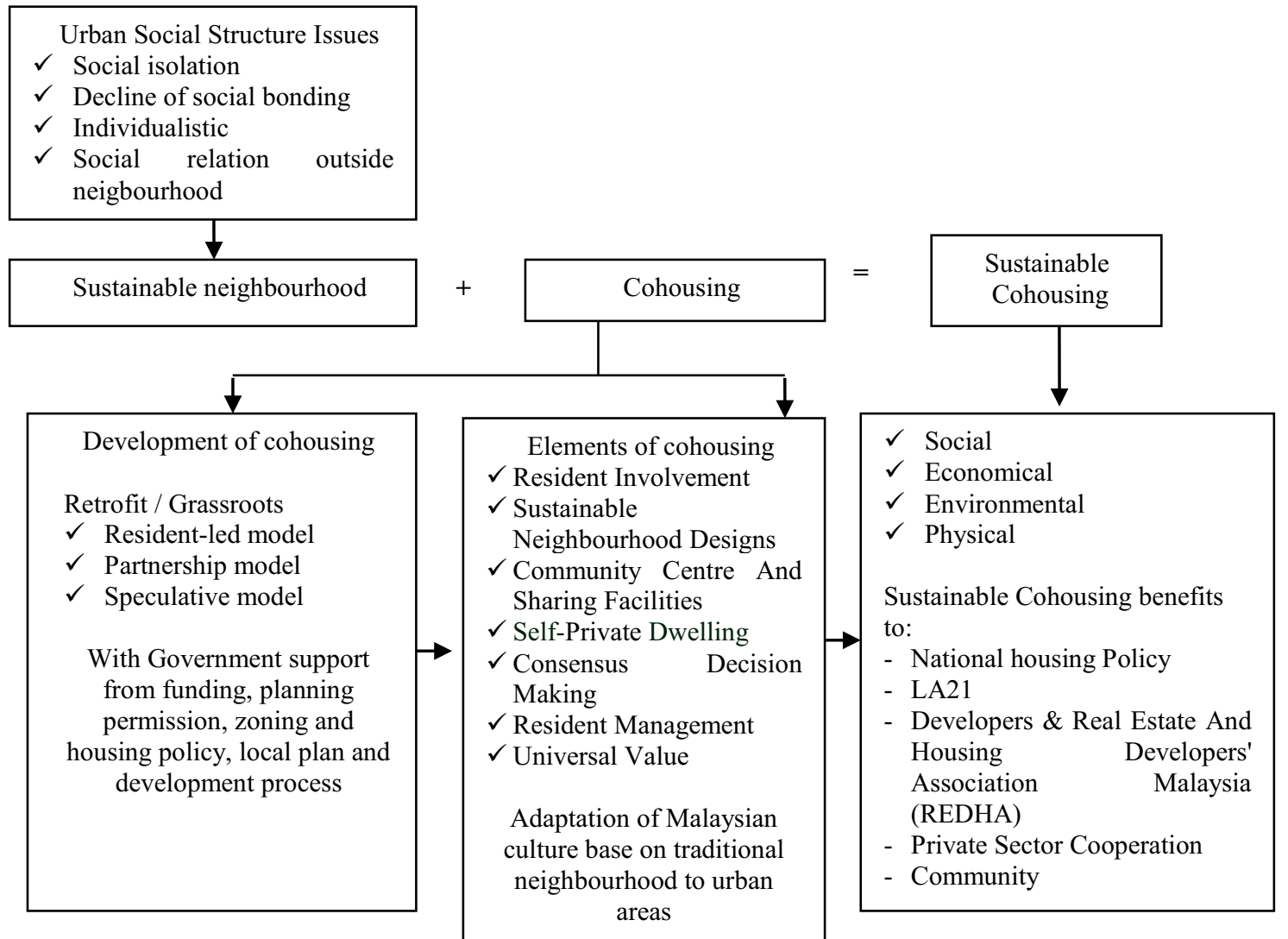

Figure 2. Conceptual Framework of Cohousing Development in Malaysia

Figure 2 above indicates one of the solutions of the urban social structure issue through an effective sustainable neighbourhood. Cohousing is seen to be the best medium of a sustainable neighbourhood that can be practiced. Strong social networks and social cohesion, environmental values in a highly effective fashion, physical design layout to fulfill community criteria in the present and future needs, community initiative incorporated to green building materials, minimise impact to the natural environment and the efficient use of land consumption are examples of Cohousing benefits to sustainability.

Moreover, Cohousing will also seen as a versatile housing concept since it is applicable to be developed either in urban or rural settings by adaption of new (grassroots) or existing settlements (retrofit). The 3 models' adoption must be supported by the government from funding, planning permission, zoning and housing policy, local plan, development process and many more to ensure the successfulness of the cohousing intention. Meanwhilst the elements of Cohousing development in Malaysia must be based on the present and suit the local culture. 7 suggested elements have been proposed in this research by adding the Universal value and Self-Private Dwelling to respect and foster social relations amongst multiracial groups in one community. As discussed by different scholars the Cohousing elements can benefit with a sustainable value; thus, it will assist Malaysia in achieving its sustainable agenda in housing development.

However, this paper has only discussed the basic idea of sustainable Cohousing. The Cohousing development requires more time to develop as all the participants need to really understand the knowledge, commitment, and how the process of Cohousing will be implemented. The findings from this study can be adapted into the future sustainable housing concept and can be presumed as the basis for recommendations to improve social cohesion amongst Malaysians.

\section{References}

1. P. Ibrahim, A. Ab Rahman, S. Arni Basir, Sustainable Economic Development : Concept, Principles And Management From Islamic Perspective, European Journal Of Social Sciences, (2011)

2. United Nation, World Population Prospects The 2015 Revision Key Findings And Advance Tables, (2015)

3. K.C. Seto, B. Güneralp, L.R. Hutyra, Global Forecasts Of Urban Expansion To 2030 And Direct Impacts On Biodiversity And Carbon Pools, Proceedings Of The National Academy Of Sciences Of The United States Of America, Pp. 1-6, (2012)

4. Ho Chin Siong, Urban Governance And Rapid Urbanization Issues In Malaysia, Jurnal Alam Bina, Jilid 13: No.4, (2008)

5. Giddens, A. Sociology (6th Ed.). Cambridge: Polity Press. (2009).

6. Carijn Beumer, Social Cohesion In A Sustainable Urban Neighbourhood, Website Http:/Www.Icis.Unimaas.Info/WpContent/Uploads/2010/07/Beumer-2010-SocialCohesion-Theory,(2010) 
7. Forrest, R., \& Kearns, A. Social Cohesion, Social Capital And The Neighbourhood. Urban Studies, 38(12), 2125-2143, (2001)

8. Schoenberg S 1979: Criteria For The Evaluation Of Neighborhood Viability In Working Class And Low Income Areas In Core Cities Social Problems 27: 69-85, (1979)

9. Lietaert M., Cohousing's Relevance To Degrowth Theories, Journal Of Cleaner Production, (2009)

10. Williams, J. Predicting an American future for cohousing. Futures,40(3), 268-286, (2008)

11. Ruiu M. L, The Social Capital Of Cohousing Communities,Sociology,

Sagepub.Co.Uk/Journalspermissions.Nav, (2015)

12. Ruiu M. L, The Effects Of Cohousing On The Social Housing System: The Case Of The Threshold Centre, Journal House And The Built Environment, 30:631-644, Springer Science Business, (2015)

13. Meltzer, G. (2005). Sustainable Community: Learning From The Cohousing Model. Canada: Trafford.

14. Mccamant, K., \& Durret, C., Creating Cohousing: Building Sustainable Community. Canada: New Society Publichers, (2011).

15. Williams. J, Designing Neighbourhoods For Social Interaction-The Case Of Cohousing, Journal of Urban Design 10 (3) (2005).

16. Riseborough M., Work On The Wild Side: For Commissioners And Housing And Social Care Providers, Housing Learning \& Improvement Network, Www.Housinglin.Org.Uk, (October 2013, Retrieve On $29^{\text {th }}$ December 2015)

17. Leafe Christian D. Creating A Life Together: Practical Tools To Grow Ecovillages And Intentional Communities. New Society Publishers; (2003)

18. Charles L. Belk, 2006, Cohousing Communities: A Sustainable Approach To Housing Development, Submitted To Sustainability And The Built Environment (062gbd101), Uc Davis Extension, Retrieve On 20 $0^{\text {th }}$ November 2015, Website Https://Extension.Ucdavis.Edu/Sites/Default/Files/ Co_Housing.Pdf.

19. Meltzer, Graham. Cohousing And Ecovillages: A Personal Take On Their Similarities And Differences. In Living Together-Cohousing Ideas And Realities Around The World, Ed. Dick Urban Vestbro, 105-113. Stockholm, Universitetsservice Us Ab. (2010)

20. C. Marcus, K. Dovey, Cohousing-An Option For The 1990s, Progressive Architecture 6 (1991) 112113., (1991)

21. J. Williams, Sun, Surf And SustainabilityComparison Of The Cohousing Experience In California And The Uk, International Planning Studies Journal 10 (2) (2005).

22. Parker Williams, Retrieve On $20^{\text {th }}$ Nov, 2015, Website Http://Bioclimaticx.Com/WpContent/Uploads/2012/02/The-Ecological-DesignOf-Co-Housing_2.Pdf,(2012)

23. Torres-Antonini, M., Hasell, M., \& Scanzoni, J., Cohousing As A Basis For Social Connectedness
And Ecological Sustainability. In G. Moser, E. Pol, Y. Bernard, M. Bonnes, J. Corraliza, M. Giuliani, ... M. Giuliani (Eds.), People, Places, And Sustainability (Pp. 123-130). Ashland, Oh Us: Hogrefe \& Huber Publishers. (2003)

24. Wright D. \& Saville G., Putting Neighbors Back In The Neighborhood: Strategies For Safety, Urban Design, And Cohousing, Presented To The 3rd International Cpted Conference, Washington, Dc. (1998)

25. Dezfooly R. M, Sustainable Criteria Evaluation Of Neighbourhoods Through Residents' Perceived Needs, International Journal Of Architecture And Urban Development Vol. 3, No. 2, Spring (2013)

26. Northwest Report, Cohousing: A Model For Sustainable Living, Number 19, January 1996 Issn 1040-855x,

Http://Www.Smartcommunities.Ncat.Org/Articles/ Cohouse.Shtml, (1996)

27. Mockler, R., Cohousing-L Discussion, Retrieved On November 24, 2015 From Http://Lists.Cohousing.Org/Archives/ Cohousingl/Msg22441.Html, (2005)

28. G. Meltzer, Co-Housing Bringing Communalism To The World? International Communal Studies Association, Communal Living On The Threshold Of A New Millennium: Lessons And Perspectives, In: Proceedings Of The Seventh International Communal Studies Conference, 2001, Pp. 25-27. (2001)

29. Krokfors, K., Co-Housing in the Making. Alexandrine Press. (2012).

30. Zhang Rui And Lv Yanhang, A New Living Concept Based On Low -Impact Strategy - The Sustainability Of Cohousing Community, Green Building Technologies And Materials, Advance Materials Research, Vol 224, Pp 220-223, (2011)

31. Assadourian, Engaging Communities For A Sustainable World, In Starke, L. (Ed.) State Of The World 2008: Innovations For A Sustainable Economy. New York: W.W. Norton. (2008)

32. Sanguinetti, A., The Design Of Intentional Communities: A Recycled Perspective On Sustainable Neighborhoods. Behavior And Social Issues, 21, 5-25. (2012).

33. Tan, T.H., Measuring The Willingness To Pay For Houses In A Sustainable Neighborhood, International Journal Of Environmental, Cultural, Economic \& Social Sustainability, 7, 1 - 12. (2011)

34. N. Aimran Samsudin, N. Mohd. Afif Osman, The Significance Of Traditional Malay Kampongs Communal Outdoor Space On Social Relation Case Study: Johor State, Retrieved On Jan 2016 From Https://Www.Academia.Edu/6292241/The_Signific ance_Of_Traditional_Malay_Kampongs_Communa 1_Outdoor_Space_On_Social_Relation_In_Johor (2014)

35. Eric C. Thompson, Rural Villages As Socially Urban Spaces In Malaysia, Urban Studies, Vol. 41, No. 12, 2357-2376, (2004)

36. Ma, Z. B. M. R., \& Alwi, E. A. Z. E. Social Interaction Among Muslims And Buddhists In 
Kampung Tendong, Pasir Mas, Kelantan, Malaysia. International Journal Of Business And Social Science, 2(1), (2014)

37. Tan T. H, Sustainability And Housing Provision In Malaysia, Journal Of Strategic Innovation And Sustainability Vol. 7(1) (2011) 